\title{
scripted
}

Volume 15, Issue 1, August 2018

\section{Book review: Copyright and Information Privacy: Conflicting Rights in Balance}

\author{
Federica Giovanella \\ Cheltenham, UK: Edward Elgar, 2017. 352 pages. \\ ISBN 9781785369353. £100 \\ Reviewed by Ruth Flaherty* \\ (ㄷ) (1) $\circledast \Theta$ \\ (C) 2018 Ruth Flaherty \\ Licensed under a Creative Commons Attribution-NonCommercial- \\ NoDerivatives 4.0 International (CC BY-NC-ND 4.0) license
}

DOI: $10.2966 /$ scrip.150118.135

* PhD Candidate, Norwich Law School, University of East Anglia, Norwich, UK, r.flaherty@uea.ac.uk 
Federica Giovanella, a Post-Doctoral Fellow in Private Comparative Law at the University of Trento, has published her first solo monograph, an investigation of the "thorny issue" of how lower courts balance the users' right to informational privacy with the rights of copyright holders to enforce infringement actions. Using this topic as a fascinating case study, Giovanella draws on experience from her $\mathrm{PhD}$ and background working in high-level European and Canadian research institutes to walk the reader though complex issues relating to the jurisprudence in three different legislatures - the US, Canada, and Italy. The US and Italy were chosen due to their size and influence on international law (Italy as an example within the EU), and Canada as tool for comparison between the two different constitutional systems. Throughout the work, the metaphor of weights, measures, and balances is used to great effect, especially given its focus on jurisprudence.

The most valuable contribution the book offers is a clear explanation of how judges in these locations attempt to balance different sets of rights in the new digital economy, and how judicial ideas relating to the importance of each right (copyright vs. informational privacy) can affect future legal thinking. By focusing on cases where copyright holders have requested personal information from ISPs relating to users accused of peer-to-peer and other illegal forms of filesharing, the arguments in this research can be expanded to cover other similar topical cases, for example relating to user generated content. This is especially important given the discussion to date in Europe about the liability of websites that host potentially infringing material.

The argument is structured clearly around an introductory chapter and literature review (Chapter 1), which, given the author's focus on balance, is well answered by her conclusions in Chapter 5 . The internal meat of the book is provided in Chapters 2, 3, and 4, in which she describes in detail the legislation in her chosen countries in relation to copyright and file-sharing (Chapter 2) and 
data protection (Chapter 3). To round out this analysis detailed case histories, which relate to copyright holders requesting personal information relating to potential infringers from ISPs, are laid out in Chapter 4. These demonstrate that, at least in these locations, when judges have been asked to balance the scales between copyright and privacy, it is privacy that is deemed the more weighty of the two rights.

A clear, concise overview of knowledge in this area of the philosophy of law is given in Chapter 1, drawing on reading from esteemed jurists such as Dworkin, Barak, Aleinikoff, and Alexy. ${ }^{1}$ The overview is clearly broken into sections explaining how the author envisages the idea of "balancing rights" and how academic thought has covered it in the past in the specified locations. This approach builds a precise understanding that enables the reader to follow the author through the explanation of how courts handle the specific conflict at hand in order to arrive at her proposed hypothesis of a new form of "conceptual balancing", whereby the constitutional conception of each right should be central to the discussion of its importance when balancing it against other rights.

This form of balancing is important since Giovanella explains how this area of normative, indistinct decision-making has created conflicts that are left open and without well-defined boundaries or rules for judges to follow. In order to solve this conundrum, it is shown that judges in all courts (including lower courts) have needed to weigh the importance of the interests at stake. The examination of exactly how this balance has been made is where this work is situated.

1 See Ronald Dworkin, Taking Rights Seriously (Cambridge, Mass.: Harvard University Press, 1977); Aharon Barak, "Proportionality and Principled Balancing" (2010) 4(1) Law \& Ethics of Human Rights 1-16; Thomas Aleinikoff, "Constitutional Law in the Age of Balancing" (1987) 96(5) Yale Law Journal 943-1005; Robert Alexy, "Constitutional Rights, Balancing, and Rationality" (2003) 16(2) Ratio Juris 131-140. 
The detailed analysis is commenced in Chapter 2, where Giovanella undertakes a comparative doctrinal review of national laws on copyright and file sharing in the three jurisdictions. The constitutional provisions covering the protection of musical works is laid out, showing the development of global thinking in relation to the global issue of file-sharing infringements. The liability of online intermediaries is discussed in detail, which is exceedingly timely given this precise topic is being debated by the European Parliament in 2018 as part of work around the proposed Directive on Copyright in the Digital Single Market. ${ }^{2}$

A similar analysis is carried out in Chapter 3 in relation to personal data protection legislation, in another well-written analysis. The author explains the difference between privacy law and personal data protection/informational privacy (p. 137). She states her belief that informational privacy is the most important form, given the prevalence of the Internet and the fact physical privacy often relies upon informational privacy. This is followed by a discussion of how each of the three jurisdictions protects privacy within its constitution and its laws, before turning to an area of potential controversy: the consent of the data subject regarding the processing of sensitive information. ${ }^{3}$ Giovanella refers to consent as "one of the cornerstones of all Italian and Canadian legislation" (p. 190). This section demonstrates her belief that data subjects should be endowed with the ability to choose exactly how their data is disclosed, as a form of "empowerment" (p. 138). The chapter finishes with an explanation of how differently the data

2 European Commission, Proposal for a Directive of the European Parliament and of the Council on copyright in the Digital Single Market, available at https://ec.europa.eu/digitalsingle-market/en/news/proposal-directive-european-parliament-and-council-copyrightdigital-single-market (accessed 20 February 2018).

3 Consent is not required for the processing of normal data under the General Data Protection Regulation (GDPR). 
protection authorities have approached their roles in each country, grouping Canada and Italy together and offering the US as a comparator.

Chapter 4 contains the progress of cases relating to copyright infringement online and privacy concerns within the three specific countries, before also examining the European Court of Justice's historical approach and giving a comparison of each institution's methods. The chapter commences with the US, because the first cases in this area were brought by the Recording Industry Association of America (RIAA). The US and Canada are shown to have a similar approach - with explicit tests laid out to explore whether and when the user's privacy rights should overcome the rights of the copyright holder to litigate infringement cases. Giovanella shows that, by contrast, Italy has no specific test.

The outcome of the analysis is that America is the friendliest location for copyright holders to litigate in, because their rights tend to prevail over user rights. Italy and Canada seem to fall the other way, where decisions tend to favour the privacy rights of users. In all cases, individual judicial interpretation of the legislation is given a lot of sway, which may lead to inconsistent results and a concurrent effect on legal certainty in this area.

Giovanella concludes her research in Chapter 5, where she returns to her idea of the "conception" of the two rights (p. 296), and her claim that the birth and development of these rights have had an effect on how important judges believe them to be when attempting to balance them. America and Italy are paired in relation to the relatively strong protection of their copyright legislation, while Italy is paired with Canada because of the potency of their information privacy laws. The final section of the work concludes with Giovanella's agreement with the statement from prominent privacy scholars that "EU law 
views privacy as a fundamental right, while the US considers it one interest that is balanced against others" (p. 305). ${ }^{4}$

In conclusion, this was a very informative work in a developing area of law. Through a detailed reading of this book, it seems it would be most useful to academic readers in the fields of jurisprudence and intellectual property law, especially those with a comparative strand to their research (although this reader has no doubt privacy scholars may also find it fascinating). The to-the-point analysis of how copyright has developed in these countries in the face of filesharing infringers and the shadow of informational privacy law, through an examination of the jurisprudential ley-lines that run underneath, gives this work a unique and valuable structure. It would be interesting to see this research updated to reflect the impact of both the Directive on Copyright in the Digital Single Market and the GDPR.

4 Paul Schwartz and Daniel Solove, "Reconciling Personal Information in the United States and European Union" (2014) 102(4) California Law Review 877-916, pp. 880-881. 